\title{
Behavior and Loading of Suspended Sediment and Nutrients from River Basins in the Hilly Catena Under Intensive Agriculture Cropping: A Case Study in Upper Kotmale Basin in Sri Lanka
}

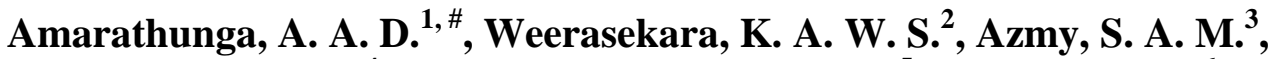 \\ Sureshkumar, N. ${ }^{4}$, Wickramaarchchi, W. D. N. ${ }^{5}$ and Kazama, F. ${ }^{6}$ \\ ${ }^{1,6}$ Interdisciplinary Graduate School of Medicine and Engineering \\ University of Yamanashi, 4-3-11, Takeda, Kofu, Yamanashi, 400-8511, Japan \\ 1,2,3,4,5 National Aquatic Resource Research \& Development Agency \\ Colombo 15, Sri Lanka \\ ${ }^{\#}$ Corresponding Author \\ Tel. +94 11252 1006; +8155220 8193; Fax. +94 11252 1009; +81552208193
}

Email: deeptha@nara.ac.lk; deeptha.amarathunga@gmail.com

\begin{abstract}
Suspended matter and nutrient are major factors for water pollution studies and this study is focused on behavior and loading of suspended sediment and nutrient in Upper Kotmale Basin (UKB). Nanu Oya, Dambagasthalawa Oya and Agra Oya are three major streams fed by Kotmale Oya proper in UKB. Eight sampling locations were selected considering all major rivers and eight months samples were collected on monthly basis. Data analysis is used cluster analysis and descriptive statistic was used for analysis of nutrient and suspended sediment loading in streams. Results reveal that, highest nutrient loads bring by Nanu Oya and calculated mean daily nutrient loads namely; ammonia- $N$, nitrite- $N$, nitrate- $N$, and dissolve phosphate were found to be in Agra Oya; $33.6 \mathrm{~kg} /$ day, $2.3 \mathrm{~kg} /$ day, $383.1 \mathrm{~kg} /$ day and $48.2 \mathrm{~kg} /$ day, Nanu Oya; $64.1 \mathrm{~kg} /$ day, $9.1 \mathrm{~kg} /$ day, $1459.1 \mathrm{~kg} /$ day \& $530.4 \mathrm{~kg} /$ day and Dabagasthalawa Oya; $19.5 \mathrm{~kg} /$ day, $1.7 \mathrm{~kg} /$ day, $310.6 \mathrm{~kg} /$ day \& $109.6 \mathrm{~kg} /$ day respectively. Also, the calculated highest suspended sediment (SS) load were found to be in Agra Oya; 4839 kg/day, Nanu Oya; 22083 kg/day and Dambagasthalawa Oya; 5843 kg/day respectively. Therefore, Nanu Oya contribute highest SS and nutrient load to Kotmale Oya proper, because of landuse change. This scenario is vulnerable to deterioration of the water quality and aquatic environment in downstream and Kotmale Oya proper.
\end{abstract}

KEYWORDS: Upper Kotmale basin, Nutrient loading, Suspended sediment load, Water pollution 


\section{Introduction}

Various anthropogenic activities influence the land uses in river basins whereas replacement of forests with impervious surfaces during urbanization can have significant impacts on watershed hydrology and riparian functions. One such concern is decrease in water quality, which is generally reflected by an increase in particulate matter in streams (Webb and Walling, 1992; Mulliss et al., 1996). The composition and concentration of particulate matter in the aquatic environment is affected by the source and pathway of sediment input (Eisma, 1993; Webster et al., 1990). Sediment discharge is increased when the product of water discharge and Suspended Sediment Concentration (SSC) increase. Additionally, the mobility of coarse material tends to increase with the larger flow velocities associated with larger discharges (Gray et al., 2000).

The eroded soil is washed away with the runoff and sedimented in the beds of the reservoirs. This causes in massive reductions of the reservoir capacities and spilling of the reservoirs even with few inches of rainfall. Therefore, suspended sediment has long been recognized as an important contaminant affecting water resources (Osterkamp et al., 1998). So that, analytical methods measuring the SSC, measure all the sediments in the entire water-sediment mixture of the original sample (Gray et al., 2000).

Water quality can be affected when watersheds are modified by alterations in vegetation, industrialization, urbanization, or conversion of forests and grasslands to agriculture and silviculture (Turner and Rabalais, 1991; Vitousek and Farrington, 1997; Carpenter et al., 1998). Both point and non-point sources of nutrients contribute to impairment of water quality. In flowing systems, nutrients may be rapidly transported downstream and the effects of nutrient inputs may be uncoupled from the nutrient source, further complicating nutrient source control (Turner and Rabalais, 1991).

Riverine habitats of Sri Lanka are rapidly being altered through many anthropogenic activities such as intensive agricultural activities, heavy agrochemical usage, damming, discharging various waste materials and industrial effluents and deforestation (Amarathunga et al., 2010a, Amarathunga et al., 2013). Several studies were conducted on water pollution and aquatic ecology in the Upper Mahaweli Catchment (UMC) in the recent past and various factors were identified as the contributing factors in deteriorating water quality in rivers and reservoirs in Sri Lanka (Sureshkumar et al., 2007; Weerasekera et al., 2009; Amarathunga et al., 2010b; Azmy et al., 2010; Shirantha et al., 2010a; Shirantha et al., 2010b).

Kotmale reservoir is highly sensitive towards eutrophication and blooming effect mainly due to nutrient loading from UMC (Piyasiri, 1995). Therefore, nutrient 
loading is very important to understand the water quality impact on the aquatic environments of the Upper Kotmale Basin (UKB). However, no studies considered the loading of suspended sediments and nutrients in the UKB. Therefore, the objective of this study is focused on the behavior and determination of suspended sediment and nutrient loading in UKB.

\section{Methodology}

\section{Study Area}

The Kotmale sub-catchment is located in Nuwara- Eliya District and $70 \mathrm{~km}$ in length which is one of the major tributaries of the Mahaweli River at the head water. Kotmale sub catchment drains an area of $571.20 \mathrm{sq}$. $\mathrm{km}$, which is about 18.8 $\%$ of the total extend of the UMC. The average annual rainfall ranges from 2000 $\mathrm{mm}$ to above $4500 \mathrm{~mm}$, and the elevation ranges from $600 \mathrm{~m}$ to $2524 \mathrm{~m}$ at Piduruthalagala.

The major part of its catchment contains vast areas of agricultural land including several tea estates. Agro-chemicals used in these cultivated areas got leached into the reservoir from numerous non-point sources (De Alwis and Azmy, 1996). Figure 1 shows the study area of UKB with Agra Oya, Dambagasthalawa Oya and Nanu Oya, which are tributaries of the Kotmale Oya that drains the western slope of the highest region of the hill country at an elevation between $2000 \mathrm{~m}$ and $2500 \mathrm{~m}$.

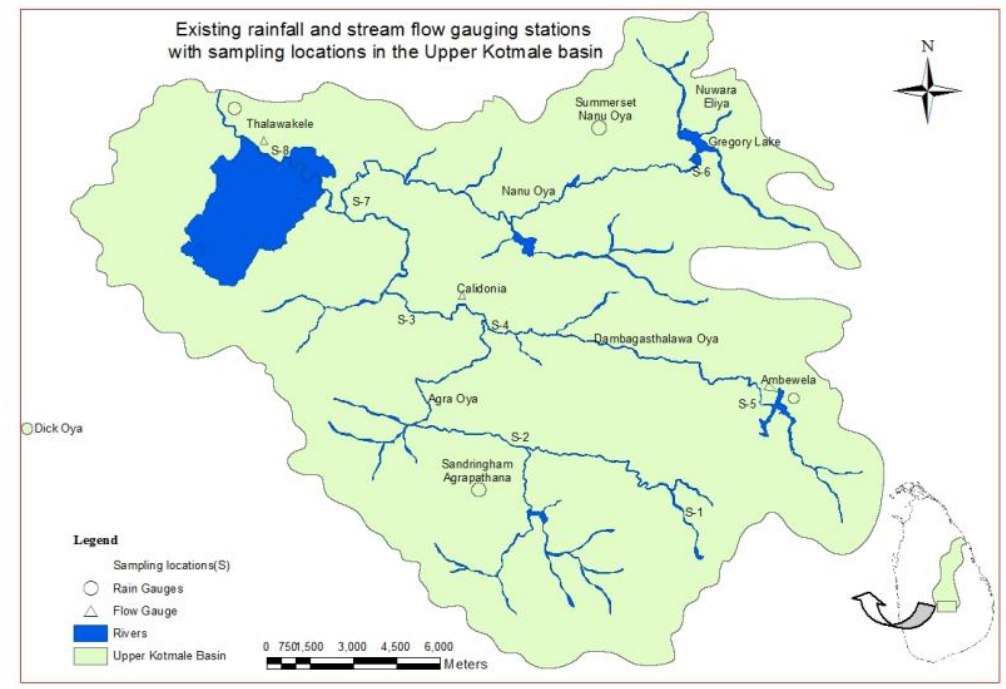

Figure 1: Rain fall and stream flow gauging stations with sampling locations in the study catchment 
The Agra Oya and Dambagastalawe Oya descend along steep gradients and join together at the Caledonia Estate and flow westward until Talawakelle, where the stream turns sharply northward before it merges with the Nanu Oya to form the Kotmale Oya proper (Silva, 1996). A major portion of the highland of the island comprises of a charnokite-meta-sedimentary series of Precambrian origin. The watershed of the Kotmale Oya is composed mainly of quartzite and gneiss. Soils in the watershed are tropical wet-zone types (Mapa et al., 1999).

\section{Surface Water Sampling}

Eight months samples were collected on a monthly basis in eight sampling locations (Figure 1): Dayagama (S-1) and Waverley (S-2) for Agra Oya; Blackpoll (S-6), and Palmerstone Division in Palmerstone Estate for Nanu Oya (S-7); Ambewela (S-5) and Waltream estate (S-4) for Dabagastlawa Oya; Lindula (S-3), and Thalawakele (S-8) for Kotmale Oya. Two samples were collected and three replicated were used for analysis in each sampling locations and mean value used for the data analysis.

\section{Analysis of Samples}

Ammonia nitrogen, nitrate nitrogen, nitrite nitrogen and orthophosphate were analyzed in accordance with the Standard Methods for Examination of Water and Waste Water (APHA, 1998). In addition, SSC was determined using a filtration method (Guy, 1969). In-situ analysis was conducted for the determination of $\mathrm{pH}$ (Orion 260A); dissolved oxygen (Orion 830A); turbidity (Hatch 2100P); total dissolve sediment (TDS); and water temperature (thermometer). The flow rate was measured using a portable flow meter (FP101) in three different places in each sampling locations in $50 \mathrm{~cm}-100 \mathrm{~cm}$ depth. Also, water depth was measured using a measuring pole and stream gauging stations at Thalawakele.

\section{Computation of Nutrient and Suspended Sediment Load}

Nutrient loads and total dissolve sediment (TDS) loads were calculated using six months data, while SSC was calculated only by four months data based on rainy and dry periods. Discharge is calculated using the formula (equation 1)

$$
\mathrm{Q}=\mathrm{A} u
$$

where $Q$ is discharge $\left(\mathrm{m}^{3} / \mathrm{s}\right), \quad A$ is the cross-sectional area of the portion of the channel occupied by the flow, $U$ is the average flow velocity $(\mathrm{m} / \mathrm{s})$. The pollution load was calculated using equation 2 where $\mathrm{L}$ is load (kg/day), $\mathrm{F}$ is unit conversion factor, $\mathrm{C}$ is concentration of pollutant $(\mathrm{mg} / \mathrm{l})$ and $\mathrm{D}$ is discharge $\left(\mathrm{m}^{3} / \mathrm{s}\right)$ (Buchanan and Somers, 1969). 


$$
L=F \times C \times D
$$

In addition, daily discharge date in 2008 in Thalawakele gauging station were from irrigation department of Sri Lanka and data used for estimate the mean monthly loads from Kotmale Oya proper in Thalawake.

\section{Data Analysis}

Microsoft Excel and SPSS-20 were used to calculate the loading of SSC and nutrients. In addition, cluster analysis was performed to the nutrients and sediment loading data sets at the each sampling locations to find out similar groups of pollutants locations. Furthest, hierarchical cluster method and measured Euclidean distance of the data sets were followed for the cluster analysis. 2008 updated land use maps were prepared using Arc GIS 10.1 version based on survey department data and land use planning division attached to District Secretariat in Nuwara-Eliya.

\section{Results}

\section{Land-use pattern and rainfall in the Upper Kotmale basin}

The land use systems in the UKB are shown in Figure 2. Tea cultivation is the dominant land use in the basin. In addition, forest reserves, intensive annual crop cultivations and plantation forests also have a significant role in the land use of the catchment. However, increasing trends of land use changes have been observed in the basin (De Silva, and Chandrasekera, 2000) due to converting of tea lands to annual crop cultivations based on their profits. In addition, home-gardens are increasing, due to high population growth.

Application of fertilizer is one of the major contributory factors which may affect the nutrient levels of the streams. Figure 3 shows total monthly rainfall variation in three sub basin, Thalawakele area and outside the study area (Dick oya). There are three peaks in the pattern and it received higher amount of rainfall to the catchment, from first inter-monsoon $(315.5 \mathrm{~mm})$, south-west monsoons $(311.5 \mathrm{~mm})$ and second inter-monsoon $(356.5 \mathrm{~mm})$.

Table 1, shows different land use type in three different sub-basin and farmers are mostly used home gardens for their annual crop cultivation. Nanu Oya was showed higher percentage of home gardens and vegetable land use type. However, agriculture is most dominant land use type in UKB. 


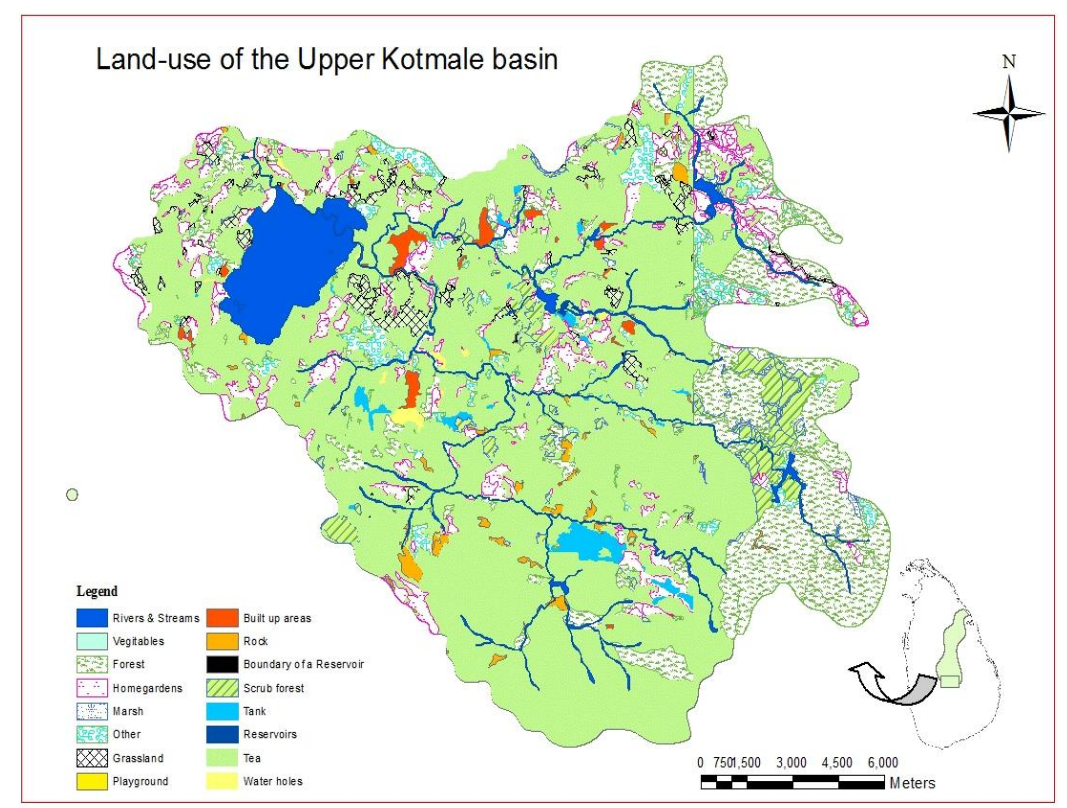

Figure 2: Land-use pattern of the Upper Kotmale basin

Table 1: Land use types and their percentages in Nanu Oya, Agra Oya and Dambagasthalawa Oya in UKB

\begin{tabular}{|l|c|c|c|}
\hline \multirow{2}{*}{ Landuse type } & \multicolumn{3}{|c|}{ Sub-catchment } \\
\cline { 2 - 4 } & Nanu Oya & Agra Oya & Dambagasthalawa Oya \\
\hline Built up land & 0.05 & 0.02 & 0.01 \\
\hline Forest - Unclassified & 19.73 & 17.2 & 42.93 \\
\hline Home gardens & 8.66 & 3.33 & 2.83 \\
\hline Marsh & 0.04 & 0.01 & 0.31 \\
\hline Other & 9.2 & 0.83 & 2.6 \\
\hline Grassland & 2.78 & 0.43 & 1.49 \\
\hline Playground & 0.04 & - & - \\
\hline Rock & 0.4 & 1.61 & 0.65 \\
\hline $\begin{array}{l}\text { Reservoir, tank, river } \\
\text { \& streams and water } \\
\text { holes }\end{array}$ & 0.96 & 2.27 & 0.82 \\
\hline scrub forest & 1.91 & 1.55 & 6.14 \\
\hline Tea cultivations & 46.21 & 71.95 & 40.11 \\
\hline Vegetable cultivations & 10.07 & 0.82 & 2.12 \\
\hline
\end{tabular}

Water temperature in the Kotmale sub-catchment was ranging from $15.7{ }^{\circ} \mathrm{C}$ to 28.5 ${ }^{\circ} \mathrm{C}$. Mean water temperature and standard deviation (SD) in the streams of Agra 
Oya, Dabagasthalawa Oya, Nanu Oya and Kotmale Oya proper were $19.0 \pm 1.0{ }^{\circ} \mathrm{C}$, $19.7 \pm 1.7{ }^{\circ} \mathrm{C}, 19.5 \pm 1.8^{\circ} \mathrm{C}$, and $21.7 \pm 2.5^{\circ} \mathrm{C}$, respectively. There was no drastic variation of the water temperature in the sub-catchments. Minimum and maximum water temperature values were recorded in the Agra Oya, Dabagasthalawa Oya, Nanu Oya and Kotmale Oya proper between $17.2^{\circ} \mathrm{C}$ to $20.1{ }^{\circ} \mathrm{C}, 16.9{ }^{\circ} \mathrm{C}$ to $22.5^{\circ} \mathrm{C}$, $15.7^{\circ} \mathrm{C}$ to $22.8^{\circ} \mathrm{C}$, and $18.7^{\circ} \mathrm{C}$ to $28.5^{\circ} \mathrm{C}$, respectively.

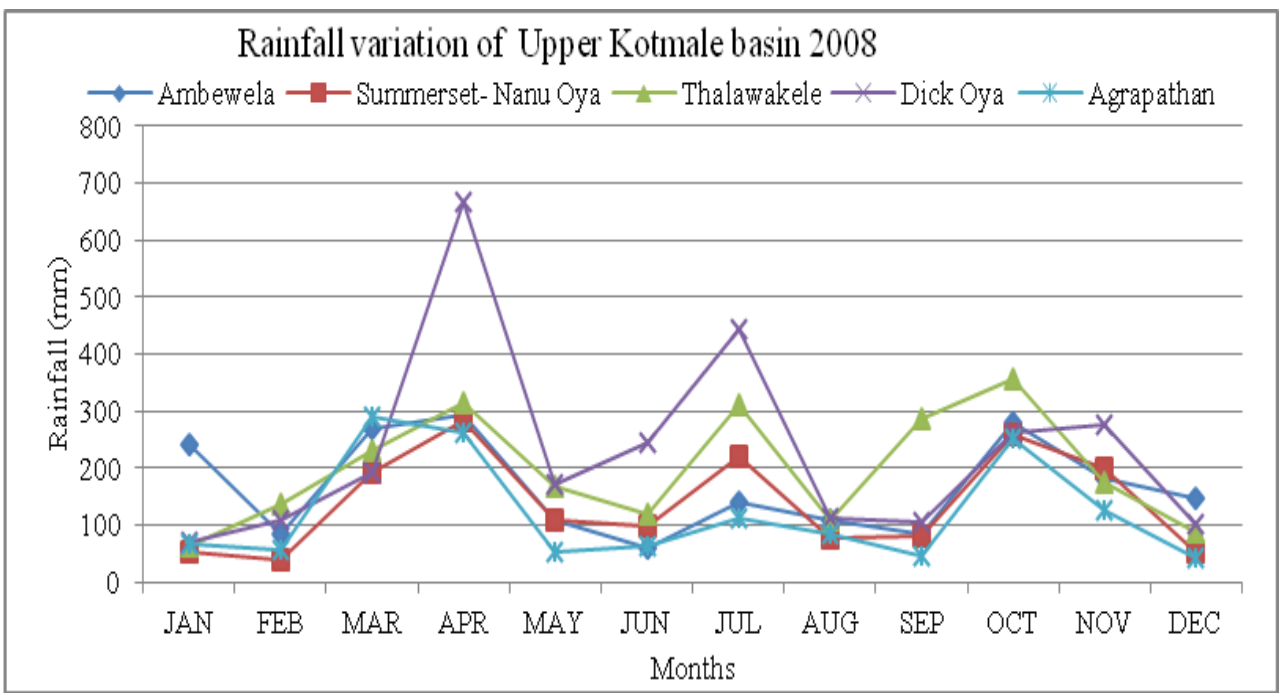

Figure 3: Rainfall variation in Upper Kotmale basin and Dick Oya- 2008

\section{Water Temperature, $p H$ and Dissolved Oxygen $\mathrm{C}$}

In general, $\mathrm{pH}$ values of surface water in the UKB were ranging from 4.8 to 7.9 , and the mean $\mathrm{pH}$ and SD values of each stream in the Agra Oya, Dabagasthalawa Oya, Nanu Oya and Kotmale Oya proper were found to be $6.34 \pm 0.6,6.6 \pm 0.6,7.1 \pm$ 0.4 , and $6.5 \pm 0.5$, respectively.

Saturation of dissolved oxygen concentrations was often observed in stream waters in the UKB and mean dissolved oxygen concentrations with SD in the Agra Oya, Dabagasthalawa Oya, Nanu Oya and Kotmale Oya proper were indicated $7.6 \pm 1.3$ $\mathrm{mg} / \mathrm{L}, 5.6 \pm 2.7 \mathrm{mg} / \mathrm{L}, 7.4 \pm 1.3 \mathrm{mg} / \mathrm{L}$, and $6.9 \pm 1.0 \mathrm{mg} / \mathrm{L}$, respectively. Lowest dissolved oxygen concentrations of $1.4 \mathrm{mg} / \mathrm{L}$ were recorded in an Ambewela reservoir in the month of May due to eutrophic conditions. 


\section{Nutrient Loading}

Nitrogen and phosphorus are the major factors responsible for the productivity of a water body. According to De Alwis and Azmy (1996), the highest recorded concentration of nitrate nitrogen was $9.8 \mathrm{mg} / \mathrm{l}$, and the present study reveals that the level of nitrate nitrogen concentration was high in the Nanu Oya, and the recorded highest value was $12.45 \mathrm{mg} / \mathrm{L}$. In addition $0.71 \mathrm{mg} / \mathrm{L}$ ammonia nitrogen was recorded in Dambagasthalawa Oya sub-basin. Table 2, show the nutrient loading per day in each month in different rivers in UKB and Table 3 shows the mean daily loading from different rivers in the UKB. Figure 4 shows the results of the cluster analysis of nutrients at upstream and downstream localities of the rivers.

Table 2: Nutrient loading different rivers from Upper Kotmale Basin

\begin{tabular}{|c|c|c|c|c|c|c|c|c|}
\hline & \multicolumn{2}{|c|}{ Agra } & \multicolumn{2}{|c|}{ Nanu Oya } & \multicolumn{2}{|c|}{$\begin{array}{c}\text { Dambagasthalawa } \\
\text { Oya }\end{array}$} & \multicolumn{2}{|c|}{$\begin{array}{c}\begin{array}{c}\text { Kotmale oya } \\
\text { proper }\end{array} \\
\end{array}$} \\
\hline & $\begin{array}{c}\text { Up } \\
\text { stream }\end{array}$ & $\begin{array}{c}\text { Down } \\
\text { stream }\end{array}$ & $\begin{array}{c}\text { Up } \\
\text { stream }\end{array}$ & $\begin{array}{c}\text { Down } \\
\text { stream }\end{array}$ & $\begin{array}{c}\text { Up } \\
\text { stream }\end{array}$ & $\begin{array}{c}\text { Down } \\
\text { stream }\end{array}$ & $\begin{array}{c}\text { Up } \\
\text { stream }\end{array}$ & $\begin{array}{c}\text { Down } \\
\text { stream }\end{array}$ \\
\hline \multicolumn{9}{|l|}{ Ammonia } \\
\hline March & 7.1 & 52.0 & 18.0 & 84.2 & 9.2 & 28.3 & 106.5 & 181.1 \\
\hline April & 12.6 & 18.2 & 19.6 & 55.4 & 4.8 & 3.6 & 8.9 & 16.0 \\
\hline May & 7.4 & 11.6 & 4.5 & 102.8 & 4.0 & 6.8 & 58.9 & 247.7 \\
\hline July & 4.4 & 65.5 & 7.2 & 61.3 & 1.0 & 22.3 & 74.5 & 139.1 \\
\hline August & 6.5 & 47.0 & 14.4 & 36.3 & 4.0 & 33.9 & 109.4 & 104.8 \\
\hline November & 4.1 & 7.1 & 14.9 & 44.4 & 2.4 & 21.9 & 75.0 & 245.2 \\
\hline Total & 42.1 & 201.4 & 78.6 & 384.6 & 25.5 & 116.8 & 433.2 & 933.9 \\
\hline \multicolumn{9}{|l|}{ Nitrite } \\
\hline March & 0.1 & 1.0 & 7.4 & 2.1 & 0.0 & 0.3 & 0.4 & 16.6 \\
\hline April & 0.1 & 1.2 & 3.4 & 25.6 & 1.0 & 2.9 & 5.3 & 22.4 \\
\hline May & 0.2 & 4.9 & 1.6 & 9.0 & 0.2 & 1.9 & 6.8 & 15.2 \\
\hline July & 0.2 & 4.2 & 1.4 & 10.3 & 0.3 & 1.9 & 6.0 & 14.4 \\
\hline August & 0.2 & 1.3 & 1.3 & 3.3 & 0.5 & 1.4 & 3.0 & 6.0 \\
\hline November & 0.3 & 1.4 & 1.7 & 4.5 & 0.0 & 1.9 & 3.6 & 13.7 \\
\hline Total & 1.1 & 13.9 & 16.8 & 54.8 & 2.1 & 10.2 & 25.2 & 88.4 \\
\hline \multicolumn{9}{|l|}{ Nitrate } \\
\hline March & 22.5 & 104.1 & 21.8 & 477.2 & 0.6 & 48.7 & 271.7 & 860.5 \\
\hline April & 1.7 & 429.7 & 679.4 & 1079.9 & 0.7 & 513.6 & 1071.6 & 1852.9 \\
\hline May & 1.0 & 17.4 & 99.2 & 1136.1 & 45.3 & 4.8 & 6.5 & 1394.2 \\
\hline July & 2.1 & 232.6 & 37.1 & 669.2 & 0.5 & 1.9 & 317.9 & 878.2 \\
\hline August & 6.3 & 260.7 & 101.7 & 635.4 & 5.3 & 211.2 & 244.1 & 1015.2 \\
\hline November & 125.8 & 1253.9 & 861.6 & 4756.9 & 5.8 & 1083.3 & 2077.0 & 7538.9 \\
\hline Total & 159.5 & 2298.3 & 1800.8 & 8754.7 & 58.1 & 1863.5 & 3988.8 & 13540.0 \\
\hline \multicolumn{9}{|l|}{ Phosphate } \\
\hline March & 13.2 & 0.0 & 389.3 & 303.2 & 1.0 & 89.2 & 53.3 & 67.9 \\
\hline April & 39.9 & 102.6 & 568.1 & 2604.2 & 62.7 & 258.6 & 1495.8 & 1327.4 \\
\hline May & 23.6 & 65.6 & 134.8 & 225.3 & 12.3 & 288.2 & 553.1 & 3513.0 \\
\hline July & 1.0 & 92.6 & 1.6 & 18.9 & 0.9 & 5.5 & 25.6 & 42.3 \\
\hline August & 0.7 & 11.4 & 1.4 & 13.9 & 1.1 & 5.7 & 23.8 & 30.6 \\
\hline November & 1.3 & 17.3 & 4.0 & 16.9 & 0.9 & 10.7 & 27.9 & 50.8 \\
\hline Total & 26.5 & 186.9 & 141.8 & 274.9 & 15.3 & 310.0 & 630.3 & 3636.7 \\
\hline
\end{tabular}




\begin{tabular}{|c|c|c|c|c|c|c|c|c|}
\hline March & 397 & 4813 & 5932 & 24984 & 656 & 3239 & 8256 & 32267 \\
\hline April & 595 & 4811 & 16775 & 27620 & 390 & 8535 & 17092 & 44566 \\
\hline May & 352 & 3074 & 2581 & 19491 & 114 & 2119 & 6320 & 25957 \\
\hline July & 316 & 2588 & 2698 & 19182 & 128 & 2081 & 6473 & 24434 \\
\hline August & 324 & 2511 & 2468 & 9985 & 192 & 2475 & 6200 & 18401 \\
\hline November & 421 & 2325 & 5444 & 13931 & 74 & 3360 & 6713 & 21083 \\
\hline Total & $\mathbf{2 4 0 5}$ & $\mathbf{2 0 1 2 3}$ & $\mathbf{3 5 8 9 8}$ & $\mathbf{1 1 5 1 9 2}$ & $\mathbf{1 5 5 4}$ & $\mathbf{2 1 8 0 9}$ & $\mathbf{5 1 0 5 4}$ & $\mathbf{1 6 6 7 0 9}$ \\
\hline SSC C \\
\hline April & 747 & 6626 & 18313 & 31774 & 464 & 12875 & 21963 & 46962 \\
\hline July & 465 & 11508 & 2698 & 28662 & 179 & 5806 & 12631 & 60084 \\
\hline August & 389 & 3746 & 2884 & 11952 & 179 & 3048 & 7297 & 23795 \\
\hline November & 557 & 3083 & 5997 & 15944 & 66 & 4545 & 8514 & 27021 \\
\hline Total & $\mathbf{2 1 5 7}$ & $\mathbf{2 4 9 6 3}$ & $\mathbf{2 9 8 9 3}$ & $\mathbf{8 8 3 3 1}$ & $\mathbf{8 8 9}$ & $\mathbf{2 6 2 7 5}$ & $\mathbf{5 0 4 0 5}$ & $\mathbf{1 5 7 8 6 3}$ \\
\hline
\end{tabular}

Units $=\mathrm{kg} / \mathrm{day}$

Table 3: Mean daily loading of nutrient, TDS and SS from different streams in Upper Kotmale Basin

\begin{tabular}{|l|c|c|c|c|c|c|c|c|}
\hline \multirow{2}{*}{\begin{tabular}{c} 
Daily $\begin{array}{c}\text { Load } \\
\text { (kg/day) }\end{array}$ \\
\cline { 2 - 9 }
\end{tabular}} & \multicolumn{2}{|c|}{ Agra } & \multicolumn{2}{c|}{ Nanu Oya } & \multicolumn{2}{c|}{$\begin{array}{c}\text { Dambagasthalawa } \\
\text { Oya }\end{array}$} & \multicolumn{2}{c|}{$\begin{array}{c}\text { Kotmale oya } \\
\text { Proper }\end{array}$} \\
\hline Ammonia & 7.0 & DS & US & DS & US & DS & US & DS \\
\hline Nitrite & 0.2 & 2.3 & 13.1 & 64.1 & 4.2 & 19.5 & 72.2 & 155.7 \\
\hline Nitrate & 26.6 & 383.1 & 300.1 & 1459.1 & 9.7 & 310.6 & 664.8 & 2256.7 \\
\hline Phosphate & 13.3 & 48.2 & 183.2 & 530.4 & 13.2 & 109.6 & 363.2 & 838.7 \\
\hline TDS & 400.9 & 3353.8 & 5983.1 & 19198.7 & 258.9 & 3634.9 & 8508.9 & 27784.8 \\
\hline SS & 539.3 & 6240.8 & 7473.3 & 22082.8 & 222.2 & 6568.6 & 12601.1 & 39465.8 \\
\hline
\end{tabular}

Unit $=\mathrm{kg}$ /day $\quad$ US - Up stream

DS - Downstream

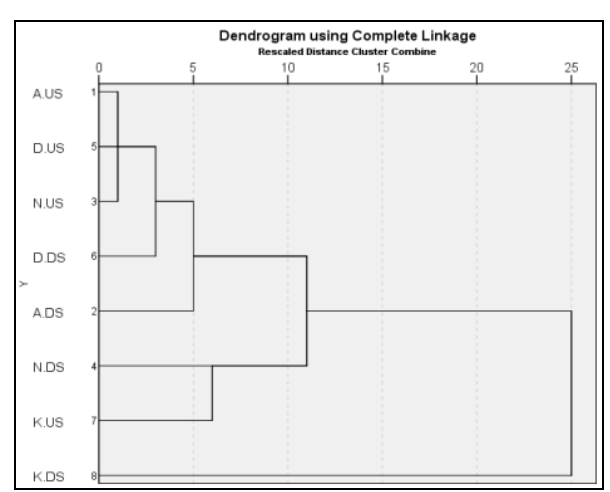

Figure 4a: Ammonia-nitrogen

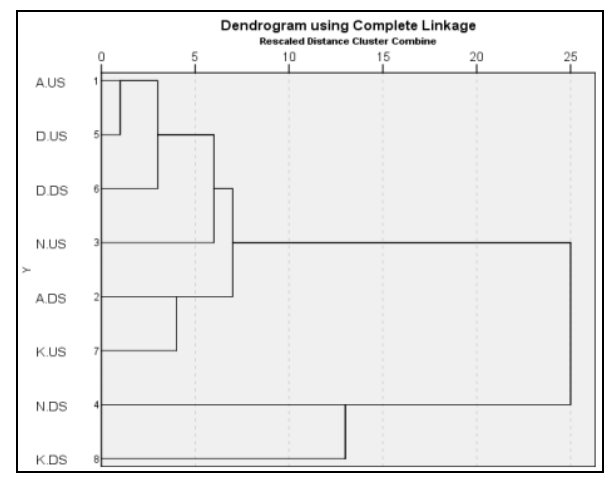

Figure 4b: Nitrite-nitrogen 


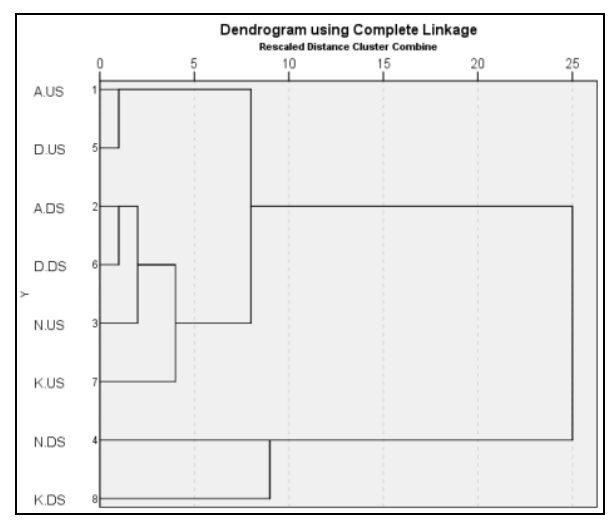

Figure 4c: Nitrate-nitrogen

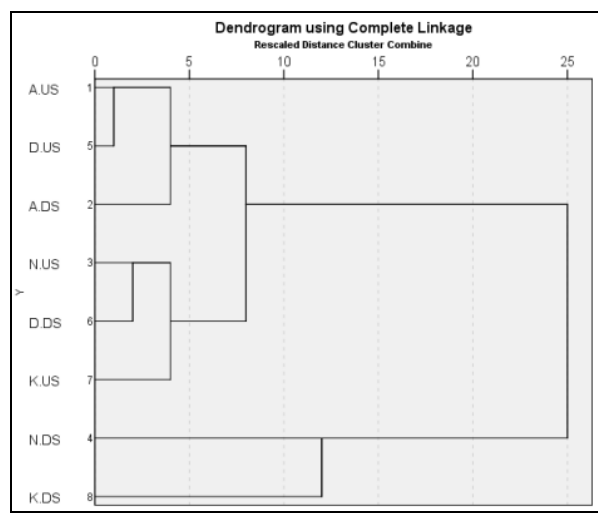

Figure 4e: SS load

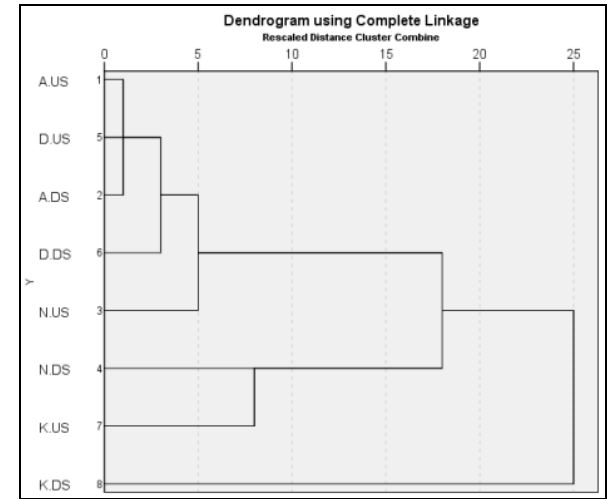

Figure 4d: Dissolve phosphate

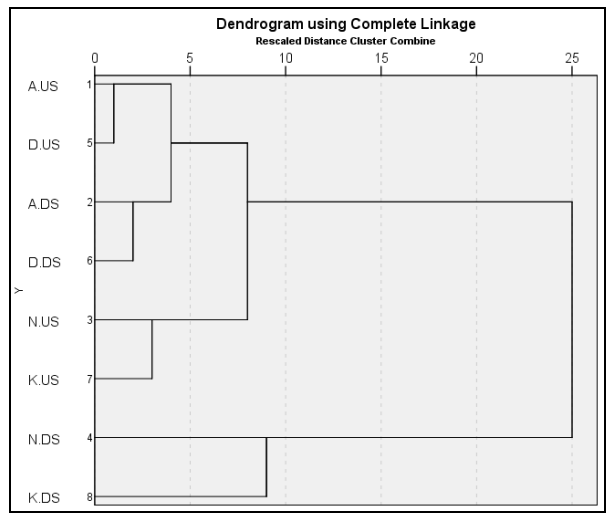

Figure 4f: TDS load

A.US = Agra Oya up stream, A.DS= Agra Oya downstream, D.US = Dambagasthalawa Oya upstream, D.DS = Dambagasthalawa Oya downstream, N.US= Nanu Oya upstream, N.DS= Nanu Oya downstream, K.US = Kotmale Oya upstream and K.DS= Kotmale Oya downstream

Figure 4: Results of cluster analysis for ammonia nitrogen (a), nitrite nitrogen (b), nitrate nitrogen (c), dissolved phosphate (d), suspended sediment load (e) and TDS load (f) loading in UKB

\section{Suspended Sediment loading}

Study revealed that the Nanu Oya sub catchment recorded comparatively elevated levels of turbidity (83.1 NTU) and SSC $(65.5 \mathrm{mg} / \mathrm{L})$. Turbidity variation in rivers is shown in Figure 5. 


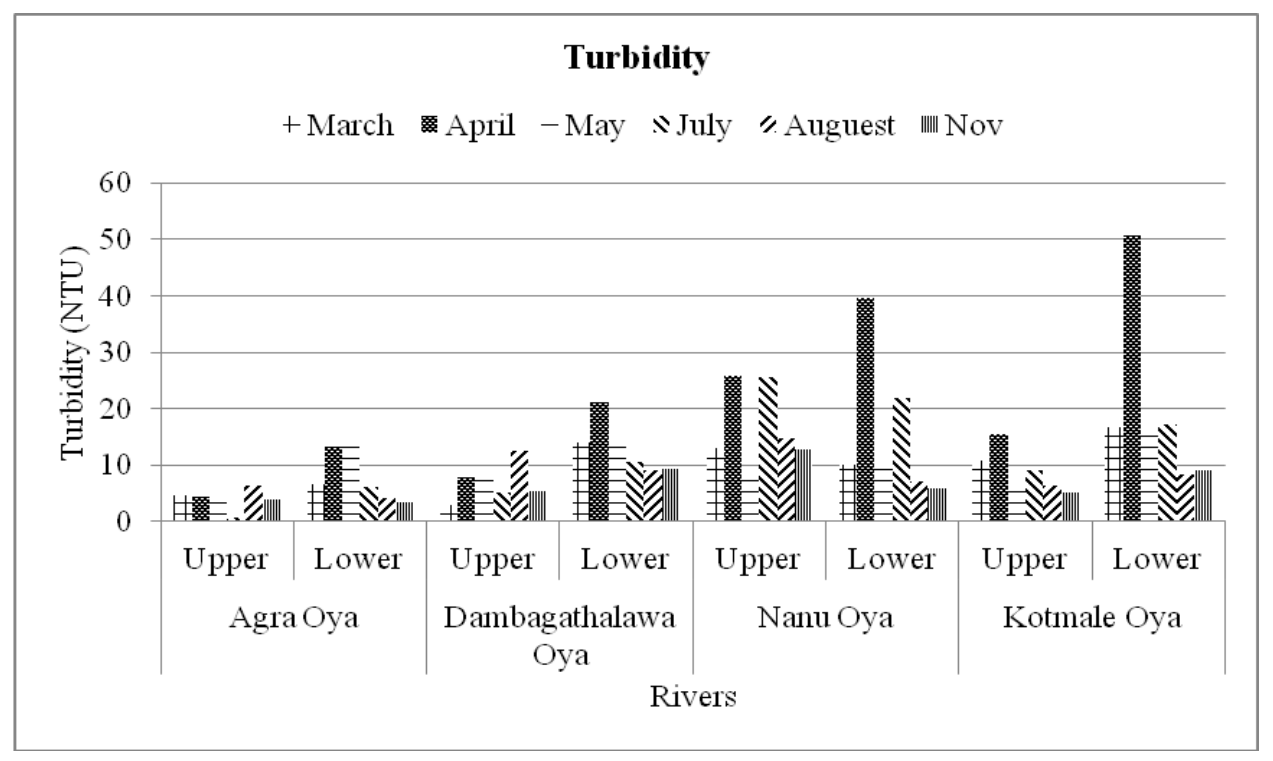

\section{Figure 5: Turbidity variation in the Upper Kotmale Basin}

The mean turbidity concentrations and SD values of Agra Oya, Dabagasthalawa Oya, Nanu Oya and Kotmale Oya proper were $8.54 \pm 9.1$ NTU, $9.97 \pm 5.0$ NTU, $22.43 \pm 22.2$ NTU and $14.97 \pm 12.4$ NTU respectively. Table 3 , is show mean daily SS and TDS loading in different stream in UKB.

Besides, mean TDS and SD values were recorded as $14.8 \pm 1.7 \mathrm{mg} / \mathrm{L}, 19.7 \pm 5.0$ $\mathrm{mg} / \mathrm{L}, 48.1 \pm 11.8 \mathrm{mg} / \mathrm{L}$ and $24.2 \pm 4.7 \mathrm{mg} / \mathrm{L}$ in above streams respectively. The mean SSC and SD values were on $18.1 \pm 14.6 \mathrm{mg} / \mathrm{L}, 24.4 \pm 9.0 \mathrm{mg} / \mathrm{L}, 50.1 \pm 11.1$ $\mathrm{mg} / \mathrm{L}$ and $36.2 \pm 13.5 \mathrm{mg} / \mathrm{L}$ respectively. Table 2 , show TDS and SSC loading from three different rivers from UKB to Kotmale Oya proper.

Figure 4 shows the results of cluster analysis for SSC and TDS in UKB and mainly two clusters were identified in each (first cluster; N. US, K. US, A. US, A. DS, D. US and D. DS, second cluster; N. DS and K. DS) based on the rescaled distance coefficients. Figure 6, show monthly loads of SSC and nutrient brought by the Kotmale Oya proper from Thalawake to the Mahaweli River. Also, results reveal that first intermonsoonal period is recorded higher loads by Kotmale Oya proper based on the seasons. 


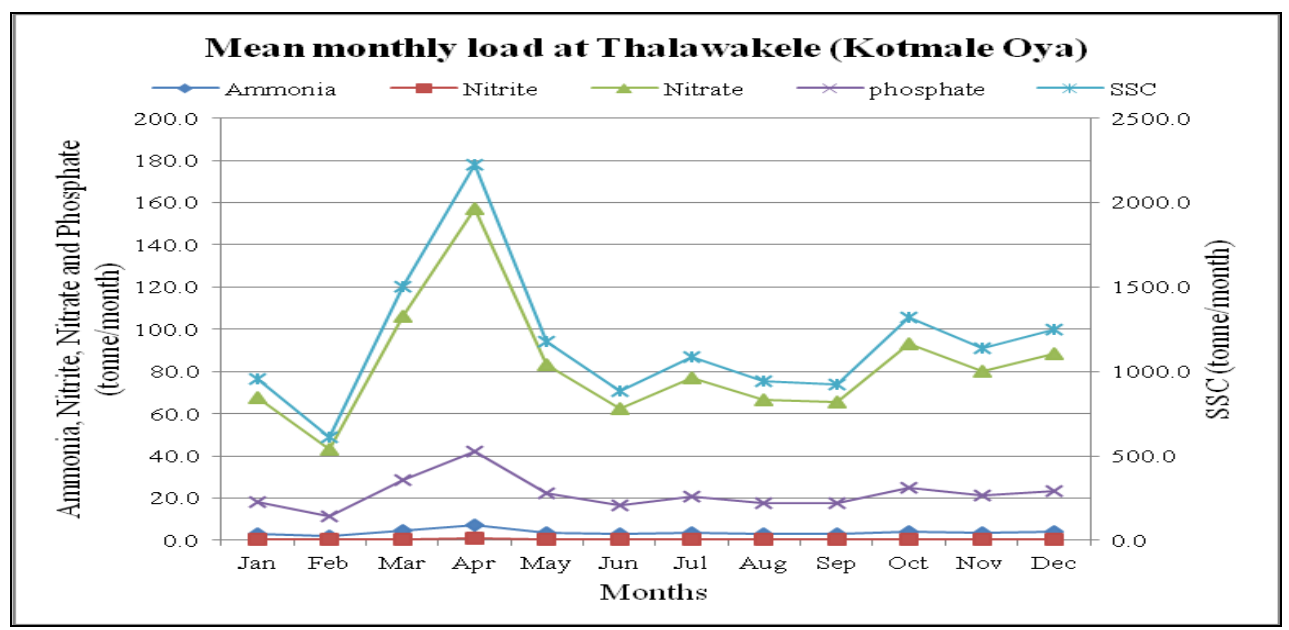

Figure 6: Mean monthly loads (calculated) from Thalawakele to Kotmale Oya

\section{Discussion}

The temperature of running water usually varies on seasonal and daily time scales, among locations, due to climate, elevation and extends of streamside vegetation (Allan, 1995). This study reveals that, the low level of temperature was recorded where the samples were collected in high elevated forest areas. There was no significant seasonal water temperature variation in the sub-catchment $(20.0 \pm 2.0$ ${ }^{\circ} \mathrm{C}$ ), because the seasonal changes in water temperature closely follow seasonal trends in mean monthly air temperature $\left(22.0 \pm 3.0^{\circ} \mathrm{C}\right)$. Also, shading by riparian forest canopies ameliorates temperature extremes (Allan, 1995).

However, air temperature variation in sampling locations (UKB) was between $16{ }^{\circ} \mathrm{C}$ to $29{ }^{\circ} \mathrm{C}$ during the study period. Lower $\mathrm{pH}$ values in the stream water, especially in the WU2 agro-ecological region in the upcountry wet zone that is attributed to the acidic nature of the soil, such as Red Yellow Podzolic soils. The $\mathrm{pH}$ is an important determinant of the electrical potential of the clay surface (Goldberg et al., 2011). These soils are acidic due to the removal of basic cataions of the soils (Mapa et al., 1999).

The minimum dissolved oxygen was recorded about $1.67 \mathrm{mg} / \mathrm{L}$ in the month of November, in Ambewela sample location (out fall of Ambewela reservoir), and the maximum value was recorded in the Nanu Oya in the month of July. Nutrient and other suspended matter (mainly organic matter) coming from annual crops cultivations and livestock farm in the upper part of the Ambewela and it created eutrophic conditions. 
The farmers in riparian area were found to have three annual crop seasons per year. They cultivate potato, cabbage, beans, leeks, radish, and other annual crops mostly three times a year. Therefore, one farming season is limited to three months. From tilling to the harvesting stage, crop lands are very frequently exposed to different agrochemicals. Residues of such chemicals rapidly go into adjoined water bodies, and thereby into nearby reservoirs and streams.

This probably increases levels of toxic compounds in water. In addition, farmers constantly use crop manure in excess. This excess amount of manure, or sometimes, all the manure if it is raining at the time of application, is washed away into a nearby water body. Water quality in streams in the upper catchment is generally linked to land use in the catchment and any changes of land use can affect the quality and quantity of water by run-off leading to deterioration of the water quality and health of the streams vigorously in downstream (Bolstad and Swank, 1997).

Higher ammonia-nitrogen loads were contributed by Agra Oya and Nanu Oya (Table 2) because of direct dispose of sewage and farm animal wastes. However, much more dramatic higher load of nitrite-nitrogen, nitrate-nitrogen and dissolve phosphate loads were brought by Nanu Oya to Kotmale Oya, because of high intensive agriculture practices in the upper catchment. According to the cluster analysis of nutrients variables, the dendrogram (Figure 4) displays possible clusters of ammonia nitrogen (Figure 4a), nitrite nitrogen (Figure 4b), nitrate nitrogen (Figure 4c) and dissolve phosphate (Figure 4d) and its relationship with each stream (upstream and downstream).

Two main clusters were recorded $\left(1^{\text {st }}\right.$ cluster; N. DS, K. US and K. DS and $2^{\text {nd }}$ cluster; N. UP, A. UP,A. DS, D. UP and D. DS) as shown in Fig. 4. Downstream of Kotmale Oya and Nanu Oya are always within the same cluster for all the nutrient parameters. The length of the branch shows how apart each case is from the other cases within its cluster. The sampling locations represent each case on the $\mathrm{Y}$ axis and the $\mathrm{X}$ axis is a rescaled distance coefficients. Cases with low distance/high similarity are close together (Aldenderfer and Blashfield, 1984). According to De Alwis and Azmy (1996), the highest recorded concentration of nitrate was 9.8 $\mathrm{mg} / \mathrm{L}$, and the present study reveals that the level of nitrate concentration was high in the Nanu Oya, and the recorded highest value was $11.81 \mathrm{mg} / \mathrm{L}$.

Some fractions of nitrate is recycled by aquatic biota when running between point and non point source pollution locations to downstream locations (Allan, 1995) before reach to the Kotmale reservoir. Nitrate nitrogen shows much higher loads than the other nutrient parameters when the monthly basis nutrient loads are considered. Additionally, results reveal that, phosphate load is significantly higher in Dabagsthalawa Oya because of farm animal waste contaminated the stream by 
runoff. Various legal and illegal anthropogenic activities were observed in the Kotmale sub-catchment, such as, development activities, gem mining, sand mining, agricultural intensification, liquid and solids waste disposal into streams, deforestations etc.

According to De Silva, (1993), water and soil degradation within these sub-basins are mainly due to extensive agricultural practices, unplanned settlement schemes, industrial activities and tea plantations. In addition, upper part of the UKB is entirely covered by intensive agricultural systems; mainly tea, vegetables (annual crops) with home gardens with some forest patches. Table 1, land use data prove that the agricultural (tea+vegitables) land use systems are higher in Nanu Oya subbasin is lower than other two sub-basins.

Recently, some parts of the tea plantations were replaced by annual crop cultivation in the upper part of the basin. Also, there is an increase in disturbed areas: mainly by cropping lands and settlements, which led to increases the rate of runoff. Thus, streams with natural channel morphologies suffer high bank erosion and export greater amounts of sediment (Kerr, 1995. and Booth et al, 1997). However, streamside vegetation reduces both sediment and nutrient transport, because substantial nutrient loss from agricultural watersheds occurs in association with sediments (Osborne and Kovacic, 1993; Osmond et al, 2002).

The analysis reveals that, highest TDS load were observed in month of April in all rivers, due to higher erosion take place with high rainfall received to sub-basins. Nanu Oya contributes the highest TDS loads to Kotmale Oya proper than Agra Oya and Dambagasthalawa Oya as low forest cover because of intensive agriculture and poor soil management practices.

However, 255,000 tons/yr suspended sediment yield was recorded at Peradeniya in the Mahaweli river (NEDECO, 1979). According to our findings, Nanu Oya stream brought the highest total suspended sediment load to Kotmale Oya proper which is 8,060 tons/yr during study the period. Also, Kotmale Oya proper was recorded 14,208 tons/yr total suspended sediment in study period.

Cluster analysis for SSC and TDS (Figure 4e and Figure 4f) shows most similar condition in Nanu Oya downstream and Kotmale Oya proper downstream. Nanu Oya has recorded $83.1 \mathrm{NTU}(22.43 \pm 22.2 \mathrm{NTU})$ as the highest turbidity among the study sub-basins. This land use is one of the greatest factor influencing changes in SSC or turbidity levels in water bodies (Bartram and Balance, 1996; Madej et al., 2012). This turbidity levels is also influenced by the input of tea dust into adjacent streams by tea factories in the basin. 
Table 4 showed mean turbidity and total suspended solids (TSS) concentrations in some Sri Lankan rivers and streams. It shows mean turbidity and TSS values in major rivers, lower basin part of the river basin and some up catchment streams. In addition, this study revealed that Nanu Oya contribute highest SSC load (Table 2) to Kotmale Oya proper. Three peaks of rainfall patterns contribute higher amounts of rainfall to the basin (Figure 3), mainly by first and second inter-monsoons and south-west monsoons. Therefore, very high-level sediment load was contributed to Kotmale Oya proper.

Table 4: Mean turbidity and TSS in various rivers and streams in Sri Lanka

\begin{tabular}{|c|c|c|c|c|c|c|c|}
\hline \multirow[b]{2}{*}{ Parameter } & \multicolumn{7}{|c|}{ Rivers/Streams } \\
\hline & $\begin{array}{l}\text { Dik } \\
\text { Oya }\end{array}$ & $\begin{array}{l}\text { Atabag } \\
\text { e Oya }\end{array}$ & $\begin{array}{l}\text { Goraka } \\
\text { Oya }\end{array}$ & $\begin{array}{l}\text { Kelani } \\
\text { River } \\
\text { (Ambathale) }\end{array}$ & $\begin{array}{l}\text { Walawe } \\
\text { River }\end{array}$ & $\begin{array}{l}\text { Menik } \\
\text { River }\end{array}$ & $\begin{array}{l}\text { Kirindi } \\
\text { Oya }\end{array}$ \\
\hline $\begin{array}{l}\text { Turbidity } \\
\text { (NTU) }\end{array}$ & $\begin{array}{c}21.6 \pm \\
10.4\end{array}$ & $\begin{array}{c}20.7 \pm \\
14\end{array}$ & $\begin{array}{c}25.7 \pm \\
41.2\end{array}$ & $12.6 \pm 1.3$ & $\begin{array}{c}16.9 \pm \\
1.3\end{array}$ & $\begin{array}{c}14.5 \pm \\
7.4\end{array}$ & $16.9 \pm 1.3$ \\
\hline TSS (mg/l) & $\begin{array}{c}13.5 \pm \\
9.7\end{array}$ & $\begin{array}{c}15.7 \pm \\
12.8\end{array}$ & $\begin{array}{c}39.7 \pm \\
61.4\end{array}$ & $\begin{array}{l}25.5 \pm \\
29.3\end{array}$ & $\begin{array}{c}17.8 \pm \\
27.3\end{array}$ & $\begin{array}{c}10.7 \pm \\
7.0\end{array}$ & $9.3 \pm 3.2$ \\
\hline References & $\begin{array}{l}\text { Azmy } \\
\text { et al, } \\
2010\end{array}$ & $\begin{array}{l}\text { Azmy } \\
\text { et al } \\
, 2010\end{array}$ & $\begin{array}{l}\text { Azmy et } \\
\text { al ,2010 }\end{array}$ & $\begin{array}{c}\text { Silva, } \\
\text { 1996; } \\
\text { NRESASL, } \\
1991\end{array}$ & $\begin{array}{l}\text { Amarath } \\
\text { unga, } \\
2006 ; \\
\text { Sureshku } \\
\text { mar et al, } \\
2007\end{array}$ & $\begin{array}{c}\text { Amarath } \\
\text { unga, } \\
2006 ; \\
\text { Sureshku } \\
\text { mar et al, } \\
2007\end{array}$ & $\begin{array}{c}\text { Amarathu } \\
\text { nga, 2006; } \\
\text { Sureshku } \\
\text { mar et al, } \\
2007\end{array}$ \\
\hline
\end{tabular}

According to the SSC loads in monthly basis (Figure 6), the highest load in reported in the month of April because of cultivation practices starting, poor soil management practices and high rainfall. Higher loads of SS may impact the reservoir water storage and this lead to negative impacts on the recently built Upper Kotmale reservoir, if proper land-use policies and monitoring systems are not introduced to the Upper Kotmale Basin.

\section{Conclusions}

The Nanu Oya sub catchment is the most critical area that is subjected to soil erosion and sedimentation. Conversions of traditional tea lands to annual crop cultivations are significantly contributing to the deterioration of the aquatic environments. Nanu oya show higher nitrate nitrogen load because of the vegetable land use pattern when compare with other sub-basins and also brought highest nutrient loads to Kotmale Oya proper. In addition, highest turbidity of 83.1 NTU is recorded in Nanu Oya.

This study revealed that higher SSC and TDS loads are contributed by Nanu Oya to Kotmale Oya proper. Also, high SS loading will impact to Upper Kotmale reservoir 
in future. In terms of study parameters, all the studied water quality and sediment parameters show higher levels in Nanu Oya than Agra Oya and Dambagasthalawa Oya. These pollution loads arising from the adjacent environments trigger changes to the biological communities of the streams in the Kotmale sub-catchment.

\section{Acknowledgements}

The Authors would like to express their gratitude to NARA for financial support. Authors are thankful to Mr. R.W. Fernando for the technical supports provided and to Mr. J. Rademaker for improving this manuscript.

\section{References}

Aldenderfer, M. S. and Blashfield, R. K., (1984). Cluster Analysis: Sage university paper series on quantitative applications in the social sciences, Newbury Park, CA.

Allan, J. D., (1995). Stream ecology: Structure and function of running waters, Clawer academic publishers, Netherlands.

Amarathunga, A. A. D., (2006). Water quality in three river system. Technical report, National Aquatic Resource Research \& Development Agency (NARA), Sri Lanka.

Amarathunga, A. A. D., Weerasekara, K. A. W. S., Sureshkumar, N., Azmy, S. A. M., and Shirantha, R. R. A. R., (2010-a). Total Suspended Solids and Turbidity co-relation and its impact on aquatic community in Kotmale sub-catchment in the Upper Mahaweli Watershed in Sri Lanka. Water Resource Research in Sri Lanka. October, 2010, Sri Lanka. 115-124

Amarathunga, A. A. D., Weerasekara, K. A. W. S, Shirantha, R. R. A. R., Sureshkumar, N., and Azmy, S. A. M., (2010-b). Nutrient Loading in Nanu Oya, Dabagasthalawa Oya and Agra Oya in Mahaweli Upper Catchment of Sri Lanka, "New Horizons in Humanities and Science Towards Sustainable Development", 26-28 August 2010, Sabaragamuwa University of Sri Lanka. 137

Amarathunga A. A. D., Jinadasa, S. U. P. And Azmy, S. A. M. (2013). Sedimentary Characteristics and Status of Water Quality in Polwatta River, and Weligama Bay in Sri Lanka. Journal of Environmental Professionals Sri Lanka. 2(1): 38-51

APHA, (1998). Greenburg A.E., Rhodes T.R., and Lenore S.C. Standard Methods for the Examination of Water and Wastewater, 20th edition, APHA/AWWA/WEF

Azmy, S. A. M., Amarathunga, A.A.D., Shirantha, R. R. A. R., and Weerasekara, K. A. W.S., (2010). Study of Nutrient Variation and Physico-chemical characteristics including bio-indicators of the Dik Oya Basin in Mahaweli Upper Catchment in Sri Lanka." Forestry and Environment", 26-27, November, 2010, University of Sri Jayawardenapura, Sri Lanka. 25 - 32. 
Bartram, J., and Balance, R., (1996). Water Quality Monitoring - A Practical Guide to the Design and Implementation of Freshwater Quality Studies and Monitoring Programmes. United Nations Environment Programme and the World Health Organization. ISBN 0419223207 (Hbk)

Bolstad, P.V., and Swank, W.T., (1997). Cumulative impacts of landuse on water quality in a southern appalachian watershed. Journal of the American Water Resources Association, 33(3): 519-533

Booth, D. B., Montgomery, D. R., and Bethel, J. P., (1997). Large woody debris in urban streams of the Pacific Northwest: in Roesner, L.A., ed., Effects of watershed development and management on aquatic ecosystems: Engineering Foundation, August 4-9, Snowbird, Utah, 178-197.

Buchanan, T. J. and Somers, W. P., (1969). Discharge Measurements at Gaging Stations: U.S. Geological Survey Techniques of Water-Resources Investigations, 1: 51-75

Carpenter, S. R., Kitchell, J. J. C., J. F., and Pace, M. L., (1998). Impact of dissolved organic carbon, phosphorus, and grazing on phytoplankton biomass and production in experimentallakes. Limnol. Oceanogr. 43: 73-80.

De Alwis, P. and Azmy, S. A. M., (1996). Eutrophic changes associated with natural phenomena in Kotmale reservoir in Sri Lanka. "Kasumigaura conference on Rivers" Kasumigaura, Japan.

De Silva, R. P. and Chandrasekera, M., (2000). Impacts of Land Use Changes on Hydrological Regime - A Case Study of Randenigala and Kotmale Catchments. Available http://www.gisdevelopment.net/application/nrm/water/overview/wato0012.htm (Retrieved on 12 July 2013).

De Silva, W. P. R. P. (1993). Determination of Water Resources Sustainability of the Upper Mahaweli Catchment by Time Series Analysis, Tropical Agriculture Research, 5: 1114.

Eisma, D. (1993). Suspended Matter in the Aquatic Environment. Springer-Verlag, Berlin, Germany.

Gray, J. R., Glysson, G.D., Turcios, L. M., and Schwarz, G. E., (2000). Comparability of suspended-sediment concentration and total suspended solids data: U.S. Geological Water-Resources Investigations, 00-4191, 14

Goldberg S., Lebron, I., Seaman, J. C., and Suarcz, D. L., (2011). Soil colloidal behavior in: Hung, P. M., Li, Y., and Sumner, M. E., (Eds.), Handbook of soil science; properties and process. CRC press, Boka Raton, Florida. 15.1 - 15.39 
Guy, H. P., (1969). Laboratory theory and methods for sediment analysis: U.S. Geological Survey Techniques of Water-Resources Investigations. 01-4217, 12

Kerr, S. J. (1995). Silt, turbidity and suspended sediments in the aquatic environment: an annotated bibliography and literature review [online]. Ministry of Natural Resources, Ontario. Available from http://www.mnr.gov.on.ca/stdprodconsume/groups/lr/@mnr/@letsfish/documents/do cument/228131.pdf (Retrive on 12 July 2013)

Madej, M. A., Bundros, G., and Klein, R., (2012). Assessing Effects of Changing Land Use Practices on Sediment Loads in Panther Creek, North Coastal California. Coast redwood forests in a changing California, USDA, $101-109$.

Mapa, R. B., Somasiri, S. and Nagarajah, S. (1999). Soils of the Wet Zone of Sri Lanka: Morphology, Characterization and Classifications., Soil Science Society of Sri Lanka. 01

Mulliss, R. M., Revitt, M., Shutes, R. B. (1996).The Impacts of Urban Discharges on the Hydrology and Water Quality of an Urban Watercourse.The Science of the Total Environment.189/190: 385-390.

NEDECO, (1979). Mahaweli Ganga development programme implementation strategy study. Mahaweli Development Board and NEDECO

NRESA, (1991). Natural Resources of Sri Lanka. Natural resources, energy and science authority of Sri Lanka.

Osborne, L. L., and Kovacic, D. A., (1993). Riparian vegetated buffer strips in water-quality restoration and stream management. freshmler Biology. 29: 243-258

Osmond, D. L., J. W. Gilliam and R. O. Evans. (2002). Riparian Buffers and Controlled Drainage to Reduce Agricultural Nonpoint Source Pollution, North Carolina State University, Raleigh, NC. 318,

Osterkamp, W. R., P. Heilman, and L. J. Lane. (1998). Economic considerations of a continental sediment monitoring program. International Journal of Sediment Research 13:12-24.

Piyasiri, S., (1995). Eutrophication and blue green algal problem of Kotmale reservoir of Sri Lanka. In: K.H. Timotius \& F. Goltenboth (Ed.), Tropical limnology, 11: 1-7,

Shirantha, R. R. A. R., Amarathunga, A. A. D., and Weerasekara, K. A. W. S., (2010-a). Lake Gregory, alien flora and urban aqua-environments in a misty city of Sri Lanka. International Conference on Sustainable Built Environment, 13-14 December 2010, Sri Lanka, 52-61. 
Shirantha, R. R. A. R., Amarathunga, A. A. D. and Weerasekara, K. A. W. S., (2010-b). Existing challenge to succeed a sustainable built aqua-environment in misty green valleys in the hill country of Sri Lanka; a case study. International Conference on Sustainable Built Environment, 13-14 December 2010, Sri Lanka, 344-354.

Silva, E. I. L. (1996). Water quality of Sri Lanka, Institute of Fundamental Studies, Sri Lanka.

Sureshkumar, N., Amarathunga, A. A. D. and Wickramaarachchi, W. D. N., (2007). Comparison of physico - chemical characteristics and pollution trends of the Menik Ganga, Kirindi Oya and Walawe Ganga. Trophycal Aquatic Research towards sustainable development, 15-16 February 2007, NARA, Sri Lanka, 41.

Turner, R. E. and Rabalais. N. N., (1991). Changes in Mississippi River water quality this century and implications for coastal food webs. BioScience 41(3): 140-147.

Webb, B. W. and Walling, D. E. (1992). 'Water Quality II. Chemical characteristics', in Calow, P. and Petts, G. E. (Eds), The Rivers Handbook. Blackwell Scientific Publications, London, 73-100.

Webster, J. R., Golladay, S.W., Benfield, E. F., Angelo, D. D. J., and Peters, G. T., (1990). Effects of Forest Disturbance on Particulate Organic Matter Budgets of Small Streams. Journal of the North American Benthological Society. 9(2): 120-140.

Weerasekara K. A. W. S., Amarathunga, A.A.D., Shirantha, R. R. A. R., Sureshkumar, N. and Azmy, S. A. M., (2009). Current Status of Ambewela Reservoir of Sri Lanka with Special Reference to Water Pollution. Forestry and Environment, 26-27 November 2010, University of Sri Jayawardenapura, Sri Lanka. 15: 85 - 92

Vitousek, P. M., and Farrington, H., (1997). Nutrient limitation and soil development: Experimental test of a biogeochemical theory. Biogeochemistry 37: 63-75. 